\title{
Penerapan Pembelajaran Model Kooperatif Tipe TAI (Team Assisted Individualization) untuk Meningkatkan Kreativitas dan Prestasi Belajar Matematika Siswa Kelas X MIPA
}

\author{
${ }^{1}$ M. Farid Nasrulloh \\ ${ }^{1}$ Fakultas Ilmu Pendidikan \\ ${ }^{1}$ faridnasrulloh@unwaha.ac.id
}

\begin{abstract}
This study aims to improve creativity and student achievement in learning mathematics in class X MIPA MA Bahrul Ulum Jombang. In general, this study seeks to increase creativity and student achievement by using a cooperative type TAI (Team Assisted Individualization) model.

This type of research is Class Action Research (CAR). The subjects of this research were 32 students of class X MIPA MA Bahrul Ulum. The object of this research is the implementation of mathematics learning using a cooperative type TAI (Team Assisted Individualization) model. This Classroom Action Research was conducted in 2 cycles, each of which consisted of 2 meetings. Data obtained from observation sheets, field notes, student creativity questionnaires, results of student and teacher interviews, cycle tests, and documentation.

The results of the study showed that using a cooperative model type TAI (Team Assisted Individualization). Can improve creativity and student achievement. Student creativity seen from all indicators of creativity has increased. In the first cycle of $58 \%$, the second cycle was $80 \%$. Creativity can be seen from the ability to produce a lot of ideas, the ability to express various kinds of solutions to problems, the ability to find answers, tend to give more answers, respond to questions asked, have many questions, and be able to describe things in detail. Mathematics learning achievement of students experienced an increase seen from the average cycle test score in class X MIPA MA Bahrul Ulum, from 62.74 to 79.84. Student learning achievement can be achieved from the changes in actions taken by changing previous learning.
\end{abstract}

Keywords: TAI, Creativity, Learning Achievement

\section{Abstrak}

Penelitian ini bertujuan untuk meningkatkan kreativitas dan prestasi belajar siswa pada pembelajaran matematika kelas X MIPA MA Bahrul Ulum Jombang. Secara umum penelitian ini mengupayakan peningkatan kreativitas dan prestasi belajar siswa dengan menggunakan model kooperatif tipe TAI (Team Assisted Individualization).

Jenis penelitian ini adalah Penelitian Tindakan Kelas (PTK). Subjek penelitian ini adalah siswa kelas X MIPA MA Bahrul Ulum yang berjumlah 32 orang. Objek penelitian ini adalah pelaksanaan pembelajaran matematika dengan menggunakan model kooperatif tipe TAI (Team Assisted Individualization). Penelitian Tindakan Kelas ini terlaksana dalam 2 siklus yang masing-masing siklus terdiri dari 2 pertemuan. Data diperoleh dari lembar observasi, catatan lapangan, angket kreativitas siswa, hasil wawancara siswa dan guru, tes siklus, dan dokumentasi.

Hasil penelitian menunjukkan bahwa dengan menggunakan model kooperatif tipe TAI (Team Assisted Individualization).dapat meningkatkan kreativitas dan prestasi belajar siswa. Kreativitas siswa yang dilihat dari semua indikator kreativitas mengalami peningkatan. Pada siklus I sebesar 58\%, pada siklus II sebesar $80 \%$. Kreativitas dapat dilihat dari kemampuan menghasikan banyak gagasan, kemampuan mengemukakan barmacam-macam pemecahan terhadap masalah, kemampuan menemukan jawaban, cenderung memberi jawaban yang lebih banyak, menanggapi pertanyaan yang diajukan, mempunyai banyak pertanyaan, dan mampu menguraikan sesuatu secara terperinci. Prestasi belajar matematika siswa mengalami peningkatan yang dilihat dari rata-rata skor tes siklus pada kelas X MIPA MA Bahrul Ulum yaitu dari 62.74 menjadi 79.84. Prestasi belajar siswa dapat tercapai dari adanya perubahan tindakan yang dilakukan dengan mengubah pembelajaran sebelumnya.

Kata kunci: TAI, Kreativitas, Prestasi Belajar 


\section{A. Latar Belakang}

Pendidikan adalah suatu proses dalam rangka mempengaruhi siswa agar dapat menyesuaikan diri sebaik mungkin terhadap lingkungan, sehingga memungkinkannya untuk berfungsi secara kuat dalam kehidupan masyarakat (2007, p.79). Pendidikan juga merupakan suatu kebutuhan yang harus dipenuhi dalam proses kehidupan.

Para ahli telah mencoba untuk menafsirkan tentang belajar. Ada yang mengatakan bahwa belajar adalah modifikasi atau memperteguh kelakuan melalui pengalaman, ini berarti belajar merupakan suatu proses kegiatan bukan suatu hasil atau tujuan. Belajar adalah kegiatan yang berproses dan merupakan unsur yang sangat fundamental dalam setiap penyelenggaraan jenis dan jenjang pendidikan (2004, p.89). Hal ini mengandung arti bahwa berhasil atau gagalnya pencapaian tujuan pendidikan itu sangat bergantung pada proses belajar yang dialami siswa, baik ketika ia berada di dalam sekolah maupun di luar sekolah. Pendidikan akan terbentuk dengan adanya proses belajar.

Menurut Undang-undang Republik Indonesia Nomor 20 Tahun 2003 tentang Sistem Pendidikan Nasional bab III mengenai prinsip penyelenggaraan pendidikan pasal 4 ayat 4 menyatakan bahwa pendidikan diselenggarakan dengan memberi keteladanan, membangun kemauan, dan mengembangkan kreativitas peserta didik dalam proses pembelajaran sehingga dalam pendidikan yang diperhatikan tidak hanya ketuntasan materi, tetapi guru juga harus mampu memberikan keteladanan, membangun kemauan dan mengembangkan kreativitas peserta didik guna mencapai keberhasilan pembelajaran. Jika proses pendidikan berhasil maka diharapkan bisa menghasilkan manusia yang berpendidikan (2008, p.62).

Berdasarkan dari hasil penelitian di Indonesia, didapatkan bahwa tingkat penguasaan peserta didik dalam matematika masih belum membanggakan. Programme for Internasional Student Assesment (PISA) pada tahun 2012 mengadakan survei prestasi belajar matematika dan Sains siswa sekolah usia 15 tahun pada 65 negara, dan Negara kita Indonesia berada pada posisi ke-64 untuk kemampuan prestasi belajar matematika (2014, p.5)

Masyarakat masih menganggap, khususnya dikalangan pelajar, matematika masih merupakan mata pelajaran sulit, membingungkan bahkan mungkin sangat ditakuti oleh sebagian pelajar. Pranoto (dalam Moch. Masykur dan Abdul Halim F) mengatakan bahwa selain kurang bervariasinya pada pengajaran yang ada, ketakutan anak didik pada matematika juga disebabkan oleh pola pengajaran guru yang otoriter, yang menganggap siswa yang banyak bertanya sebagai hal yang kurang ajar dan tidak patuh pada pola pengajaran guru, selain itu juga disebabkan oleh tekanan berlebihan kepada hafalan, kecepatan berhitung dan prestasi individu, serta banyaknya guru yang tidak memahami bahwa proses terpenting belajar matematika adalah nalar, bukan menghafal dan kemampuan menghitung, dan mereka menganggap siswa yang tidak bisa berhitung tidak pintar matematika (2007, p.35).

Salah satu masalah yang dihadapi dunia pendidikan adalah masalah lemahnya proses pembelajaran. Dalam proses pembelajaran, anak kurang didorong untuk mengembangkan kemampuan berfikir kreatif. Proses pembelajaran di kelas diarahkan kepada kemampuan anak untuk menghafal informasi. Hasil wawancara yang peneliti lakukan bahwa siswa di sekolah mempunyai beberapa permasalahan dalam pembelajaran. Diantara permasalahan tersebut adalah: kebanyakan siswa masih menganggap pelajaran matematika adalah pelajaran yang sulit dan menakutkan. Siswa masih sering lupa terhadap materi yang telah diajarkan guru. Model yang digunakan guru dalam proses belajar mengajar cenderung monoton yaitu model ekspositori (ceramah), sehingga siswa mengalami kebosanan atau kurang antusias terhadap materi yang diajarkan, kurangnya kreativitas belajar siswa terhadap matematika, terbukti dengan siswa yang jarang mengajukan pertanyaan dan kurangnya muncul ide/gagasan siswa baik dalam bentuk soal maupun penyelesaiannya.

Matematika merupakan subyek yang sangat penting untuk dipelajari dalam pendidikan formal. Bagi negara yang mengesampingkan matematika sebagai prioritas utama, maka ia akan tertinggal dari negara-negara yang mementingkan matemataika terutama berkompetensi dalam bidang ekonomi dan teknologi. Menurut Cocroft (1986) mengenai peran penting matematika, bahwa manusia akan sangat sulit atau tidak akan bisa hidup di bagian bumi ini pada abad ke-20 ini tanpa sedikitpun memanfaatkan matematika (2009, p.2). Matematika merupakan salah satu ilmu dasar yang harus dikuasai oleh siswa, sebab matematika tidak bisa dipisahkan dalam kehidupan sehari-hari. Namun hal ini kurang disadari oleh siswa disebabkan minimnya informasi yang diterima siswa tentang apa dan bagaimana matematika.

Model kooperatif (Cooperative Learning) tipe TAI (Team Assisted Individualization) merupakan rangkaian kegiatan belajar yang dilakukan oleh siswa dalam kelompok-kelompok tertentu untuk mencapai tujuan pembelajaran yang telah ditentukan. Ada empat unsur penting dalam pembelajaran kooperatif, yaitu: adanya peserta didik dalam kelompok, adanya aturan kelompok, adanya upaya belajar setiap anggota kelompok, dan terakhir yaitu adanya tujuan yang harus dicapai (2007, p.224). 
Penerapan model model kooperatif tipe TAI (Team Assisted Individualization) diharapkan dapat meningkatkan prestasi belajar dan menumbuhkan kreativitas siswa.

Kata prestasi berasal dari bahasa belanda yaitu prestastie, kemudian dalam bahasa Indonesia menjadi kata "prestasi" yang berarti hasil usaha 2009, p.02). Prestasi belajar pada umumnya berkenaan dengan aspek pengetahuan yang banyak digunakan dalam berbagai bidang dan kegiatan seperti dalam kesenian, olah raga, dan pendidikan, khususnya dalam proses pembelajaran.

Prestasi belajar siswa adalah keberhasilan siswa dalam menguasai materi pelajaran matematika yang diwujudkan dengan angka yang sering disebut dengan nilai. Sehingga dengan perwujudan nilai tersebut, prestasi antara siswa satu dengan siswa yang lainnya dapat terlihat. prestasi satu siswa dengan siswa yang lainnya biasanya berbeda.

Gagne menyatakan bahwa prestasi belajar bukan hanya berupa keberhasilan yang diwujudkan dengan angka saja tetapi lebih kepada keberhasilan yang berupa ketrampilanketrampilan intelektual yang memungkinkan untuk berinteraksi dengan lingkungan. Winkel mengatakan bahwa prestasi belajar adalah suatu bukti keberhasilan belajar atau kemampuan seseorang siswa dalam melakukan kegiatan belajarnya sesuai dengan bobot yang dicapainya (2010, p.01). Sedangkan menurut S. Nasution, prestasi belajar adalah: "Kesempurnaan yang dicapai seseorang dalam berfikir, merasa dan berbuat (1989, p.177-178). Prestasi belajar dikatakan sempurna apabila memenuhi tiga aspek, yaitu: kognitif, afektif dan psikomotor, dan sebaliknya dikatakan prestasi kurang memuaskan jika seseorang belum mampu memenuhi target dalam ketiga kriteria tersebut.

Jadi dari definisi-definisi di atas, prestasi belajar dapat diartikan sebagai hasil belajar yang telah dicapai oleh siswa pada ranah kognitif, afektif dan psikomotorik setelah proses pembelajaran, untuk mengetahui atau mengungkapkan keberhasilan seseorang setelah mempelajari sesuatu yang digunakan untuk mengukur pencapaian seseorang setelah mempelajari sesuatu materi yang akan diujikan.

Banyak orang telah berusaha untuk memahami dan mengartikan kreativitas dan mengembangkannya di lingkungan sekolah, kampus, bisnis, maupun rumah. Para peneliti memiliki perbedaan pendapat tentang pengertian kreativitas. Ada yang mengatakan bahwa kreativitas adalah kapabilitas akal (rasionalisasi), sebagian yang lain terdiri dari pribadi (person), proses (process), produk (product), dan tekanan (press).

a. Pribadi (person)

Sternberg menyatakan bahwa kreativitas merupakan titik pertemuan yang khas antara tiga atribut psikologis, yaitu intelegensi, gaya kognitif, dan kepribadian/motivasi yang secara bersamaan ketiganya dapat memahami apa yang melatarbelakangi individu yang kreatif. Intelegensi meliputi kemampuan verbal, pemikiran lancar, pengetahuan, perencanaan, perumusan masalah, penyusunan strategi, representasi mental, ketrampilan pengambilan keputusan, keseimbangan, dan integrasi intelektual secara umum (1999, p.26-27).

b. Proses (process)

Torrance mendefinisikan kreativitas adalah:

"The process of (1) sensing difficulties, problems, gaps in information, missing elements, something asked; (2) making guesses and formulating hypotheses, (3) evaluating and testing these guesses and hypothesis, (4) possibly revising and resesting them, and finally (5) communicating the results" (1999, p.27).

Torrance mengemukakan bahwa proses kreativitas dimulai dari merasakan adanya masalah, membuat perkiraan dan merumuskan hipotetis, menilai perkiraan dan hipotesis, memungkinkan untuk memperbaiki dan mengetes ulang perkiraan atau hipotesis, dan mengomunikasikan hasilnya.

c. Produk (product)

Definisi produk menekankan pada adanya unsur orisinalitas, kebaruan, dan kebermaknaan. Barron menyatakan bahwa kreativitas adalah kemampuan untuk menghasilkan/menciptakan sesuatu yang baru. Haefele menyatakan bahwa kreativitas adalah kemampuan untuk membuat kombinasi-kombinasi baru yang mempunyai makna sosial. Amabile mengemukakan bahwa kreativitas merupakan karya baru yang sesuai dengan tugas yang dihadapi.

d. Tekanan (press)

Kategori terakhir dari definisi kreatif adalah menekankan pada faktor pendorong (press). Faktor pendorong ini berasal dari diri sendiri (internal) dan dorongan dari luar (eksternal) yang berasal dari lingkungan sosial. Simpson mendefinisikan kreatif sebagai aspek dorongan dari dalam diri (internal), yaitu yang dirumuskan "the initiative that one manifest by his power to break away from the usual sequence of thought" bahwa kemampuan kreatif seseorang lebih mengarah pada kekuatan dalam diri untuk berinisiatif dan berubah dari kebiasaan lingkungan yang ada

Pembelajaran kooperatif tipe TAI (Team Assisted Individualization) ini dikembangkan oleh Slavin (2005). Tipe ini mengutamakan keunggulan pembelajaran kooperatif dan pembelajaran individual. Tipe ini dirancang untuk memberikan solusi kesulitan belajar siswa secara individual. Oleh karena itu, kegiatan pembelajarannya lebih banyak digunakan untuk pemecahan masalah, ciri khas pada tipe TAI ini adalah setiap siswa secara individual belajar materi pembelajaran yang sudah dipersiapkan oleh guru. Hasil belajar individual dibawa ke kelompok-kelompok untuk didiskusikan dan 
saling dibahas oleh anggota kelompok, dan semua anggota kelompok bertanggung jawab atas keseluruhan jawaban sebagai tanggung jawab bersama.

Pembelajaran kooperatif mempunyai karakteristik tersendiri, diantaranya yaitu: pembelajaran secara tim, didasarkan pada manajemen kooperatif, adanya kemauan untuk bekerja sama, dan adanya ketrampilan bekerja sama (2007, p.224). Pembelajaran kooperatif juga mempunyai beberapa prinsip-prinsip pembelajaran, diantaranya yaitu: prinsip ketergantungan positif (Positive Interdependence), tanggung jawab perseorangan (Individual Accountibility), interaksi tatap muka (Face to Face promotion Interaction), partisipasi dan komunikasi (Participation Communication) (2007, p.225).

Mengingat matematika berperan penting dalam berbagai aspek kehidupan, maka diperlukan model pembelajaran matematika yang mampu memberi solusi untuk mengatasi permasalahan tersebut di atas. Peneliti mencoba melakukan Penelitian Tindakan Kelas (PTK) untuk meningkatkan kreativitas dan prestasi belajar siswa pada pembelajaran matematika, yaitu model kooperatif TAI (Team Assisted Individualization).

\section{B. Tujuan Penelitian}

Tujuan dari penelitian ini adalah

1. Ingin mengetahui bahwa model pembelajaran TAI (Team Assisted Individualization) dapat meningkatkan kreativitas belajar matematika Siswa

2. Ingin mengetahui bahwa model pembelajaran TAI (Team Assisted Individualization) dapat meningkatkan prestasi belajar matematika Siswa.

\section{Metode Penelitian}

Penelitian ini merupakan jenis penelitian tindakan kelas (classroom action research). Penelitian Tindakan Kelas (PTK) dapat diartikan sebagai upaya yang ditujukan untuk memperbaiki proses pembelajaran atau memecahkan masalah yang dihadapi dalam pembelajaran (2009, p.34).

Pendekatan yang digunakan dalam penelitian ini adalah pendekatan penelitian kualitatif yang di dukung oleh data kuantitatif. Penelitian dengan pendekatan kualitatif lebih menekankan analisisnya pada proses penyimpulan induktif serta pada analisis terhadap dinamika hubungan antar fenomena yang diamati, dengan menggunakan logika ilmiah. Hal ini bukan berarti bahwa pendekatan kualitatif sama sekali tidak bisa menggunakan dukungan data kuantitatif, akan tetapi penekanannya tidak pada pengujian hipotesis melainkan usaha menjawab pertanyaan penelitian melalui cara-cara berfikir formal dan argumentatif (1998, p.5).

Desain (model) penelitian ini adalah menggunakan Classroom Action Research (CAR) yang dikemukakan oleh Kurt Lewin yang kemudian dikembangkan oleh Kemmis dan Mc. Taggart. Menurut Kurt Lewin. Penelitian Tindakan Kelas dalam pelaksanaannya berupa proses pengkajian berdaur (cyclical) yang terdiri dari empat fase pokok, yaitu:

a. Perencanaan (Planning)

Fase ini merupakan fase yang terstruktur dan terencana. Namun tidak menutup kemungkinan dapat mengalami perubahan sesuai dengan situasi dan kondisi saat itu.

b. Tindakan (Action)

Fase ini merupakan fase dimana tindakan yang dilakukan berdasarkan pada perencanaan yang telah disusun sesuai permasalahan.

c. Pengamatan (Observation)

Fase ini merupakan fase mendokumentasikan semua kegiatan yang terjadi selama penelitian.

d. Refleksi (Reflection)

Fase ini merupakan fase mengingat kembali tindakan yang dilakukan sesuai hasil observasi.

Empat fase pokok tersebut digambarkan dalam bentuk spiral yang dikenal dengan istilah action research spiral, artinya penelitian tindakan kelas dapat dimulai dari mana saja dari keempat fase yang digambarkan. Desain penelitian ini digambarkan sebagai berikut (2002, p.84) :

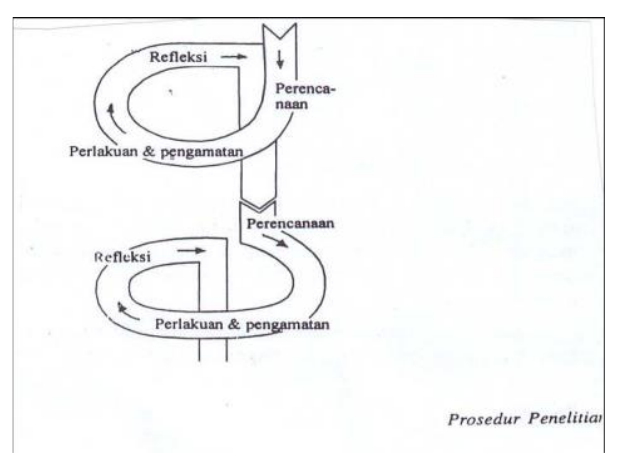

Gambar 1. Spiral Penelitian Tindakan Kelas

\section{Prosedur Penelitian}

Prosedur atau langkah-langkah yang akan dilakukan oleh peneliti dalam penelitian ini adalah sebagai berikut:

\section{a. Personel Yang Terlibat}

Penelitian ini dilaksanakan dengan melibatkan peneliti dibantu observer, guru dan siswa. Peneliti dan guru berkolaborasi sebagai pengarah dan pembimbing pembelajaran, siswa yang dikenai tindakan selama pembelajaran. Sedangkan observer bertugas mengobservasi jalannya proses pembelajaran.

\section{b. Penyusunan Instrumen Pembelajaran}

Instrumen pembelajaran yang digunakan dalam penelitian ini adalah rencana pelaksanaan 
pembelajaran (RPP) dan lembar kerja siswa (LKS). Instrumen pembelajaran tersebut sebelumnya dikonsultasikan dahulu dengan guru mata pelajaran dan validator.

\section{c.Skenario Tindakan}

Prosedur kerja dalam penelitian tindakan kelas ini direncanakan dalam bentuk siklus. Siklus berikutnya akan dilakukan bila pada siklus sebelumnya tidak memenuhi indikator keberhasilan. Masing-masing siklus direncanakan terdiri empat tahap kegiatan, yaitu:

a. Menyusun rencana tindakan.

b. Melaksanakan tindakan.

c. Melakukan observasi.

d. Membuat evaluasi dilanjutkan melakukan refleksi.

Penelitian ini dilaksanakan secara kolaboratif antara guru kelas bersama-sama dengan peneliti dan observer selama proses pembelajaran yang berlangsung sebanyak 2 siklus. Siklus I terlaksana sebanyak 2 kali pertemuan, begitu juga dengan siklus II terlaksana 2 kali pertemuan.

\section{d. Instrumen Pembelajaran dan Instrumen Penelitian}

Instrumen pembelajaran yang digunakan dalam penelitian ini adalah RPP dan LKS, sedangkan instrument penelitian yang digunakan dalam penelitian ini adalah cacatan lapangan, pedoman wawancara, lembar observasi, dan angket. Tes dan dokumentasi.

\section{e. Keabsahan Data Penelitian}

\section{Validitas Data}

Dalam penelitian kuantitatif, yemuan data dapat dinyatakan valid apabila tidak ada perbedaan antara data yang dilaporkan peneliti dengan apa yang sesungguhnya terjadi pada obyek yang diteliti (2008, p.365). Borg dan Gall (2003) merujuk kepada Anderson dan Herr untuk lima tahap kriteria validitas. Sehingga dalam PTK suatu temuan atau data dikatakan valid apabila memenuhi semua kriteria berikut: yaitu validitas demokratik, validitas hasil, validitas proses, validitas katalitik, dan validitas dialogis (2007, p.166).

\section{Validitas Empiris}

Peneliti melakukan uji validitas tes secara empirik. Pengujian validitas empirik adalah ketepatan mengukur yang didasarkan pada hasil analisis yang bersifat empirik, dengan kata lain validitas empirik adalah validitas yang bersumber pada pengamatan yang diperoleh di lapangan (1998, p.167). Sebuah tes dikatakan memiliki validitas jika hasilnya sesuai dengan keriteria dalam arti memiliki kesejajaran antara tes tersebut dengan kriteria. Teknik yang digunakan untuk mengetahui kesejajaran adalah menggunakan analisis product moment (2006, p.72), rumusnya yaitu: $r_{x y}=\frac{N \sum x y-\left(\sum x\right)\left(\sum y\right)}{\sqrt{\left\{N \sum x^{2}-\left(\sum X\right)^{2}\right\}\left\{N \sum y^{2}-\left(\sum Y\right)^{2}\right\}}}$

Keterangan:

$\mathrm{r}_{\mathrm{xy}} \quad=$ Koefisien korelasi antara $\mathrm{X}$ dan $\mathrm{Y}$

$\mathrm{x} \quad=$ Jumlah sekor item

$\mathrm{y} \quad=$ Jumlah skor total

$\mathrm{X}^{2} \quad=$ Jumlah kuadrat dari sekor item

$\mathrm{Y}^{2}=$ Jumlah kuadrat dari sekoar total

$\mathrm{xy}=$ Jumlah perkalian antara skor item dan

sekor total

$\mathrm{N} \quad=$ Jumlah soal

Adapun interpretasi mengenahi besarnya koefisien korelasi adalah sebagai berikut:

Tabel 1. Koefisien korelasi

\begin{tabular}{|c|c|}
\hline Koefisien Korelasi & Keterangan \\
\hline $0,00-0,20$ & Sangat Rendah \\
\hline $0,20-0,04$ & Rendah \\
\hline $0,04-0,06$ & Cukup \\
\hline $0,06-0,08$ & Tinggi \\
\hline $0,08-1,00$ & Sangat Tinggi \\
\hline
\end{tabular}

Dari hasil tes iuji validitas mengunakan bantuan SPSS 16 didapatkan hasil sebagai berikut:

\begin{tabular}{|c|c|c|c|}
\hline Soal & $\begin{array}{c}\text { Pearson } \\
\text { Correlation }\end{array}$ & $\begin{array}{c}\text { Sig (2- } \\
\text { tailed) }\end{array}$ & Keterangan \\
\hline 1 & $0,847(* *)$ & 0,001 & Valid \\
\hline $\mathbf{2}$ & $0,801(* *)$ & 0,002 & Valid \\
\hline $\mathbf{3}$ & $0,783(* *)$ & 0,003 & Valid \\
\hline $\mathbf{4}$ & $0,795(* *)$ & 0,002 & Valid \\
\hline $\mathbf{5}$ & $0,787(* *)$ & 0,002 & Valid \\
\hline $\mathbf{6}$ & $0,802(* *)$ & 0,002 & Valid \\
\hline $\mathbf{7}$ & $0,830(* *)$ & 0,001 & Valid \\
\hline $\mathbf{8}$ & $0,881(* *)$ & 0,000 & Valid \\
\hline
\end{tabular}

Tabel 2. Hasil Tes Siklus I 


\begin{tabular}{|c|c|c|c|}
\hline Soal & $\begin{array}{c}\text { Pearson } \\
\text { Correlation }\end{array}$ & $\begin{array}{c}\text { Sig } \\
(2 \text {-tailed) }\end{array}$ & Keterangan \\
\hline 1 & $0,792(* *)$ & 0,002 & Valid \\
\hline $\mathbf{2}$ & $0,792(* *)$ & 0,002 & Valid \\
\hline $\mathbf{3}$ & $0,833(* *)$ & 0,001 & Valid \\
\hline $\mathbf{4}$ & $0,774(* *)$ & 0,003 & Valid \\
\hline $\mathbf{5}$ & $0,979\left(^{* *}\right)$ & 0,000 & Valid \\
\hline $\mathbf{6}$ & $0,920(* *)$ & 0,000 & Valid \\
\hline $\mathbf{7}$ & $0,935(* *)$ & 0,000 & Valid \\
\hline $\mathbf{8}$ & $0,953(* *)$ & 0,000 & Valid \\
\hline
\end{tabular}

\section{Tabel 3. Hasil Tes Siklus II}

Apabila nilai signifikan $(\mathrm{p})<0,05$ maka pada nilai koefisien korelasinya terdapat tanda (**), seperti pada nilai di nilai person correlated, ini menunjukkan bahwa hasil pengujian bermkana, atau signifikan dalam hal ini butirnya valid (2007, p.155-156). Cara yang paling mudah dalam membaca hasil uji adalah berdasarkan nilai signifikansi (p) dibandingkan dengan nilai $\mathrm{a}=5 \%$, dengan nilai $\mathrm{p}<0,05$, sehingga menunjukkan bahwa item tersebut valid karena memiliki hubungan yang signifikan antara item dengan jumlah skor item. Jadi dapat disimpulkan bahwa soal tes siklus I dan tes siklus II, seluruh butir soalnya bernilai valid.

\section{Reliabilitas Data Penelitian}

Reliabilitas soal tes siklus menyangkut ketepatan alat ukur dan berhubungan dengan masalah kepercayaan, sebuah tes dikatakan memiliki tingkat kepercayaan yang tinggi jika tes tersebut dapat memberikan hasil yang tetap apabila dilakukan pengukuran kembali pada subjek yang sama (2006, p. 109). Untuk soal evaluasi berbentuk uraian, untuk menguji kehandalan soal tersebut menggunakan rumus $a l p h a$, adapun rumusnya:

$$
\mathrm{r}_{11}=\left(\frac{k}{(k-1)}\right)\left(1-\frac{\sum \sigma_{b}^{2}}{\sigma_{t}^{2}}\right)
$$

$\mathrm{r}_{11}=$ reliabilitas instrument

$\mathrm{k}=$ Banyaknya butir pertanyaan atau butir soal

$$
\begin{aligned}
& \sum_{b} \sigma_{b}^{2}=\text { jumlah varians butir } \\
& \sigma_{t}^{2}=\text { varians total }
\end{aligned}
$$

Dari hasil tes, diuji reliabilitas mengunakan bantuan SPSS 16 didapatkan hasil:

Tabel 4. Reliabilitas Statistik

\begin{tabular}{|c|c|}
\hline Soal & $\begin{array}{c}\text { Cronbach's } \\
\text { Alpha }\end{array}$ \\
\hline Tes Siklus I & 0,791 \\
\hline Tes Siklus II & 0,782 \\
\hline
\end{tabular}

Tabel diatas menunjukkan bahwa nilai seluruh Tes Siklus nilai cronbach's alpha nya di atas 0,7 sehingga semua soal tes siklus reliabel.

\section{f. Teknik Analisis Data}

Teknik analisis data yang digunakan pada penelitian ini yaitu analisis data deskriptif kualitatif. Data yang diperoleh dalam penelitian ini berupa data hasil observasi, jurnal harian, tes, wawancara, dan dokumentasi (foto). Data-data tersebut kemudian dianalisis melalui beberapa tahap sebagai berikut (2008, p.336).

\section{Display data}

Data yang telah ditriangulasikan disajikan dalam bentuk tabel. Hal ini bertujuan agar data yang disajikan lebih mudah dibaca dan dipahami. Indikator keberhasilan penelitian merupakan sesuatu yang digunakan sebagai ukuran berhasil tidaknya suatu penelitian.

Rumus yang digunakan untuk menghitung persentase data hasil angket yaitu:

$\underline{\text { jumlah bobot indikator X Nilai indikator }} \times 100 \%$

jumlah maksimum indikator

Jumlah skor maksimum $=$ jumlah siswa $\times 4$, dengan pengkategorian skor sebagai berikut:

Tabel 5. Pengkategorian Data Angket

\begin{tabular}{|c|c|}
\hline Prosentase Skor yang diperoleh & Kategori \\
\hline $80,00 \% \leq \mathbf{x} \leq 100 \%$ & Tinggi \\
\hline $60,00 \% \leq \mathbf{x} \leq 79,99 \%$ & Sedang \\
\hline $40,00 \% \leq \mathbf{x} \leq 59,99 \%$ & Kurang \\
\hline $20,00 \% \leq \mathbf{x} \leq 39,99 \%$ & Rendah \\
\hline $0 \% \leq \mathbf{x} \leq 19,99 \%$ & Sangat \\
& rendah \\
\hline
\end{tabular}

Penggunaan rumus tersebut memudahkan peneliti dalam mengolah data hasil angket serta dapat menunjukkan persentase keberhasilan pembelajaran matematika dengan menggunakan model pembelajaran model kooperatif tipe TAI (Team Assisted Individualization).

Untuk data catatan lapangan, lembar observasi pembelajaran dan wawancara akan dihitung 
menggunakan teknik non statistik karena data berbentuk kata-kata yang digunakan untuk penafsiran atau interpretasi terhadap hasil evaluasi belajar. Sedangkan untuk data bentuk tes dianalisis dan dihitung rata-ratanya untuk mengetahui apakah sudah mencapai Kriteria ketuntasan Minimum (KKM), dengan menggunakan rumus:

$$
\frac{\text { jumlah nilai hasil tes }}{\text { jumlah siswa }}
$$

Dari data hasil tes, selanjutnya dikategorikan dalam tabel seperti berikut:

Tabel. 6 pengkategorian hasil tes siklus

\begin{tabular}{|c|c|}
\hline $\begin{array}{c}\text { Prosentase Skor yang } \\
\text { diperoleh }\end{array}$ & Kategori \\
\hline $81 \% \leq \mathbf{x} \leq 100 \%$ & Tinggi \\
\hline $61 \% \leq \mathbf{x} \leq 80 \%$ & Sedang \\
\hline $41 \% \leq \mathbf{x} \leq 60 \%$ & Kurang \\
\hline $21 \% \leq \mathbf{x} \leq 40 \%$ & Rendah \\
\hline $\mathbf{x} \leq 21 \%$ & Sangat rendah \\
\hline
\end{tabular}

\section{Kesimpulan}

Langkah berikutnya adalah menyimpulkan. Dari kesimpulan tersebut dapat dilihat apakah proses pembelajaran sudah tercapai atau belum. Jika belum tercapai maka diadakan tindak lanjut (penelitian ulang), namun jika sudah berhasil maka penelitian dihentikan.

\section{g. Indikator Keberhasilan}

Pelaksanaan model pembelajaran kooperatif tipe TAI (Team Assisted Individualization) dikatakan berhasil meningkatkan kreativitas belajar siswa jika pada akhir siklus, kreativitas siswa mengalami peningkatan dari siklus sebelumnya dan dikatakan berhasil meningkatkan prestasi belajar siswa jika pada akhir siklus diperoleh data yang menunjukkan rata-rata prestasi belajar kelas di atas SKM (Standar Kelulusan Minimum), dimana SKM di MA Bahrul ulum Jombang adalah sebesar 75 dan menunjukkan adanya peningkatan dari siklus sebelumnya.

\section{Pembahasan}

Penelitian tindakan kelas yang bertujuan meningkatkan kreativitas dan prestasi belajar siswa kelas X MIPA MA Bahrul Ulum Jombang ini dilaksanakan. dalam dua siklus. Masingmasing siklus terdiri dari dua kali pertemuan.

Kegiatan pengamatan merupakan suatu kegiatan mengamati jalannya proses pembelajaran. Pelaksanaan pengamatan yang dilakukan meliputi pengamatan pembelajaran, Pengamatan pembelajaran ini difokuskan pada pengamatan terhadap proses pembelajaran yang dilakukan oleh guru, serta pengamatan kreativitas siswa yaitu pengamatan yang difokuskan pada sikap yang dilakukan siswa selama di kelas.

Pada pertemuan ini guru menyampaikan tujuan pembelajaran dan memberikan apersepsi kepada siswa mengenai materi pelajaran yang akan dipelajari. Guru menjelaskan tentang metode yang akan digunakan yaitu menggunakan model kooperatif tipe TAI (Team Assisted Individualization). Sebelum guru menerapkan model pembelajaran yang akan diteliti, guru menjelaskannya kepada siswa.

Guru meminta memberikan tugas kepada siswa untuk mempelajari materi secara individual yang sudah dipersiapkan. Selanjutnya guru memberikan kuis secara individu kepada siswa untuk mendapatkan skor dasar atau skor awal.

Setelah waktu dirasa cukup untuk mengerjakan soal kuis secara individu, guru membentuk beberapa kelompok/team. Guru meminta siswa untuk mendiskusikan jawabannya dengankelompoknya. Guru berkeliling mengawasi kerja siswa dalam kelompok. Guru membantu siswa yang mengalami kesulitan.

Beberapa siswa masih belum terbiasa berdikusi, sehingga ketika proses diskusi berlangsung masih ada pasangan yang saling tidak mau mengalah (ngeyel) menganggap pekerjaannya paling benar dan tidak mau menerima hasil pekerjaan temannya.

Setelah waktu untuk mengerjakan soal soal dirasa cukup, guru menyuruh siswa untuk mempresentasikan jawaban kelompoknya di depan kelas. Guru mempersilahkan siswa mempresentasikan hasil kerja kelompoknya tanpa menunjuk anggota kelompok tertentu. Satu dari masing-masing anggota kelompok mulai maju ke depan untuk menuliskan jawabannya di papan tulis.

Presentasi kelompok dirasa sudah cukup, guru mengadakan kuis di akhir pembelajaran sebagai langkah pada tahap terakhir model kooperatif. Siswa begitu antusias dengan adanya kuis ini dengan berebut maju mengerjakan di papan tulis. Setelah siswa selesai mengerjakan kuis, guru memberikan hadiah kepada siswa yang telah berani maju menjawab kuis yang diberikan, diikuti dengan aplouse (tepuk tangan) siswa.

Guru meminta siswa untuk tetap belajar walaupun tidak ada tugas ataupun ujian, serta meminta siswa mempelajari materi yang akan dipelajari pada pertemuan berikutnya. Guru mengakhiri pelajaran dengan salam dan siswa menjawab salam dari guru.

Rangkuman hasil observasi kreativitas siswa dengan menggunakan model kooperatif tipe TAI (Team Assisted Individualization), pada siklus II bahwa kreativitas siswa sudah mulai meningkat jika dibandingkan dengan siklus sebelumnya. Hal ini terlihat ketika siswa 
mengerjakan LKS atau kuis, sebagian siswa sudah bisa menemukan cara penyelesaian dengan cara mereka sendiri. Apabila mereka menemukan permasalahan, mereka kerjakan dengan diskusi kemudian apabila belum terselesaikan jawabannya, mereka baru bertanya kepada guru.

Ketika ada siswa yang presentasi di depan kelas dan ada yang belum faham, maka mereka langsung bertanya tentang hal yang mereka belum difahami, dan sebagian juga sudah ada yang menanggapi jawaban temannya. Dari hasil pekerjaan kelompok yang di presentasikan di depan, masing-masing kelompok sudah mampu menguraikan jawaban mereka secara terperinci. Dari hasil lembar observasi kreativitas siswa dihasilkan kreativitas siswa pada siklus II sebesar $80 \%$ yang sebelumnya pada siklus I sebesar $58 \%$.

Pada siklus yang kedua ini, peneliti mewawancarai empat orang siswa. Menurut salah seorang dari mereka mengatakan bahwa penerapan model kooperatif tipe TAI (Team Assisted Individualization) ini sudah bisa dirasakan oleh semua siswa artinya mereka sudah faham dan hafal mengenai langkahlangkah dalam model pembelajaran kooperatif tipe TAI (Team Assisted Individualization). Siswa yang lain mengatakan bahwa dengan model ini yang ada diskusi kelompoknya ini bisa menambah interaksi antar siswa, bisa melatih organisasi dan saling membantu antara teman satu dengan teman yang lain.

Hasil wawancara dapat disimpulkan bahwa dengan menggunakan model ini, kreativitas siswa dapat diwujudkan, dibuktikan dengan adanya diskusi kelompok ynag hidup saat mengerjakan LKS atau kuis, sehingga siswa dapat menyelesaikan soal LKS dengan baik.

Berdasarkan data hasil tes siklus II diperoleh nilai rata-rata individu dan rata-rata kelas yang mencapai 79.84 . Hasil tes siklus II ini sudah mencapai SKM sekolah yaitu sebesar 75, dan hasil tersebut sudah menunjukkan peningkatan prestasi belajar siswa dari siklus I (sebesar 62,74). hal ini dikarenakan siswa sudah mengikuti jalannya proses pembelajaran dengan baik dan mereka sudah melakukan persiapan sebelumnya sebelum melakukan tes evaluasi.

\section{E. Penutup}

a. Penerapan model kooperatif tipe TAI (Team Assisted Individualization) pada pembelajaran matematika kelas X MIPA MA Bahrul Ulum Jombang dapat meningkatkan kreativitas siswa. Hasil angket siswa menunjukkan adanya peningkatan kreativitas siswa dari siklus I ke siklus II yaitu sebesar $22 \%$.

b. Penerapan model kooperatif tipe TAI (Team Assisted Individualization) dapat meningkatkan prestasi belajar siswa kelas kelas X MIPA MA Bahrul Ulum Jombang. Dalam hal prestasi belajar siswa disetiap siklusnya mengalami peningkatan. Hal tersebut secara kuantitatif ditunjukkan dari rata-rata skor hasil belajar siswa, terlihat adanya peningkatan prestasi belajar siswa dari siklus I ke siklus II, sebesar 62,74 menjadi 79,84 atau meningkat sebesar 16,72 yang berarti sudah memenuhi KKM (Kriteria Ketuntasan minimum) sekolah tersebut yaitu sebesar 75. Maka peneliti menganggap bahwa dari hasil yang telah diperoleh tersebut dapat menjawab permasalahan yang diajukan dalam penelitian ini, yaitu meningkatkan prestasi belajar siswa.

\section{Saran}

Model pembelajaran kooperatif tipe TAI (Team Assisted Individualization) yang diterapkan ini berhasil sehingga model pembelajaran ini sebaiknya diterapkan dalam pembelajaran, khususnya pelajaran matematika.

\section{Daftar Pustaka}

Abdul halim F, Moch. Masykur. 2007. Mathematical Intelegence (Cara Cerdas Melatih Otak dan Menanggulangi Kesulitan Belajar). Yogyakarta: ar Ruzz Media

Amal abdul Salam Alhalili, Mengembangkan Kreativitas Anak, (Jakarta: Pustaka Alkautsar, 2005), hal 124

Azwar, Saifuddin. 1998. Metode Penelitian. Yogyakarta : Pustaka Pelajar

Arifin, Zainal. 2009. Evaluasi Pembelajaran Prinsip, Teknik, Prosedur. Bandung, Remaja Rosda Karya

Arikunto, Suharsimi. 2002. Prosedur Penelitian Suatu Pendekatan Praktik. Jakarta: Rineka Cipta

Hamalik, Oemar. 2007. Proses Belajar Mengajar. Jakarta: Bumi Aksara.

Mulyasa, E. 2009. Praktik Penelitian Tindakan Kelas. Bandung: Remaja Rosda Karya

Munandar, Utami. 1999. Kretivitas \& Keberbakatan. Jakarta: Gramedia Pustaka Utama

Sanjaya, Wina. 2006. Strategi Pembelajaran Berorientasi Standar Proses Pendidika. Jakarta: Kencana Prenada Media Group

Shadiq, Fadjar. Bagaimana Cara Guru Matematika Menunjukkan Eksistensi Matematika? Bekal Untuk Para Calon Guru Matematika. Makalah ini disampaikan pada kuliah umum Fakultas 
Sains dan Teknologi Prodi Pandidikan Matematika. tanggal 8 Mei 2009.

Slavin, Robert E. 2008. Cooperative Learning:

Theory, Research, Practice, Bandung: Nusa Media

Sugiyono. 2008. Metode penelitian pendidikan. Bandung: CV. Alfabeta

Sudjono, Anas. 1998. Pengantar Evaluasi Pendidikan. Jakarta: Raja Grafindo Persada

Syah, Muhibbin. 2004. Psikologi Pendidikan dengan Pendekatan Baru. Bandung: Remaja Rosdakarya

Tim Redaksi Fokus media.2008. Himpunan Peraturan Perundang-Undangan Tentang Guru Dan Dosen . Bandung: Fokusmedia

Wilis, Ratna D. 1989. Teori-Teori Belajar. Jakarta : P2LPTK

Wiriaatmadja, Rohiyati. 2007. Metode Penelitian Tindakan Kelas. Bandung: Remaja Rosda Karya

\section{Profil Singkat}

${ }^{1}$ M. Farid Nasrulloh, lahir pada 13 April 1987, menyelesaikan studi S1 Pendidikan Matematika di UIN Sunan Kalijaga Yogyakarta, dan menempuh S2 Prodi Pendidikan Matematika Pascasarjan UNY. Sejak 2015 s.d Sekarang mengabdi untuk belajar dan mengajar di Fakultas Ilmu Pendidikan Universitas KH. A. Wahab Hasbullah Jombang. 